\title{
Effort of Medan Mayor in Realizing Clean Government (Study About the Practice of Administration in Medan City To Prevent and Acts Criminal Actors of Corruption)*
}

\author{
Sabungan Sibarani \\ Fakultas Hukum, Universitas Borobudur \\ Jl Raya Kali Malang 1 Cipinang Melayu Jakarta Timur \\ E-mail: ssibarani01@gmail.com
}

DOI: $\underline{10.15408 / j \mathrm{jch} . v 5 i 2.4952}$

\begin{abstract}
:
The efforts of Mayor of Medan in creating a clean government in Medan City Government is to promote the rules and policies that have made the central government and implemented by the city government of Medan conditions include (a) the fact Integrity, (b) e-purchasing, (c) e-government, (d) reward (reward) and punishment (punishment), (e) unqualified (WTP) and the Procurement Services Unit (ULP). The role of the Mayor of Medan to prevent and take action against perpetrators of corruption in the city government of Medan are (a) facing the principle of transparency in carrying out the functions and duties of office to prevent corrupt practices, (b) make an early warning program of prevention of corruption, (c) and nine steps to eradicate corruption. That support wider community both from the community organizations, businesses, and students are needed.
\end{abstract}

Keyword: Policy, Transparency and Corruption.

* Received: July 09, 2017, Revised: July 23, 2017, Accepted: Agustus 22, 2017. 


\title{
Sabungan Sibarani
}

\section{Upaya Walikota Medan \\ Dalam Mewujudkan Pemerintahan Yang Bersih (Studi Tentang Praktek Penyelenggaraan Pemerintahan \\ Di Kota Medan Untuk Mencegah dan Menindak Pelaku Tindak Pidana Korupsi)}

\begin{abstract}
Abstrak:
Upaya Walikota Medan dalam mewujudkan pemerintah yang bersih di Pemerintah Daerah Kota Medan adalah dengan mengedepankan pada aturan dan kebijakan yang telah dibuat pemerintah pusat dan diimplementasikan dengan kondisi di Pemda Kota Medan diantaranya (a) Fakta Integritas, (b) e-purchasing, (c) e-government, (d) penghargaan (reward) dan hukuman (punishment), (e) Wajar Tanpa Pengecualian (WTP) dan Unit Layanan Pengadaan (ULP). Peranan Walikota Medan untuk mencegah dan menindak pelaku tindak pidana korupsi di Pemda Kota Medan adalah (a) mengedepankan prinsip transparansi dalam menjalankan fungsi dan tugas jabatannya guna mencegah terjadinya praktek korupsi, (b) Membuat program peringatan dini pencegahan korupsi. (c) dan sembilan langkah untuk pemberantasan korupsi. Di mana dukungan masyarakat luas baik dari kalangan organisasi masyarakat, pelaku bisnis, serta mahasiswa sangat dibutuhkan.
\end{abstract}

Kata kunci: Kebijakan, Tranparansi dan Korupsi.

How to cite (turabian):

Sibarani, Sabungan. "Effort of Medan Mayor in Realizing Clean Government (Study About the Practice of Administration in Medan City To Prevent and Acts Criminal Actors of Corruption)" JURNAL CITA HUKUM [Online], Volume 5 Number 2 (December 2017). 


\section{Pendahuluan}

Survei yang dilakukan pada tahun 2013 oleh transparency.org sebuah badan independen dari 146 negara, tercatat data 10 besar negara yang dinyatakan sebagai negara terkorup, diantaranya adalah : 1) Azerbaijan, 2) Bangladesh, 3) Bolivia, 4) Kamerun, 5) Indonesia. Dari daftar di atas, negara Indonesia berada di peringkat ke 5 negara terkorup di dunia, tapi di tingkat Asia Pasifik, Indonesia adalah yang terkorup, berikut adalah 5 besar negara paling korup di Asia-Pasifik, diantaranya adalah 1) Indonesia, 2) Kamboja, 3) Vietnam, Philipina dan India. ${ }^{1)}$

Fitra memaparkan hasil audit BPK mengenai audit anggaran daerah (APBD), ternyata Sumatera Utara (Sumut) menjadi provinsi nomor 1 terkorup, disusul oleh Aceh yang menempati urutan kedua. Kemudian yang ketiga adalah Papua, dan keempat DKI Jakarta. Sedangkan untuk provinsi yang paling tidak korup adalah Bangka Belitung, DIY, Bali dan Jateng termasuk yang paling baik.2)

Kementerian Dalam Negeri (Kemendagri) mencatat hingga Januari 2014 sebanyak 318 orang dari total 524 orang kepala daerah dan wakil kepala daerah tersangkut dengan kasus korupsi. Untuk itu harus ada perbaikan dalam pemilihan kepala daerah (pilkada) yang diadakan pada 2015 atau setelah pelaksanaan pemilihan umum legislatif 9 April 2014 serta pemilihan presiden 9 Juli 2014.3)

Jumlah itu terdiri dari keterlibatan gubernur sebanyak 21 orang, wakil gubernur tujuh orang, bupati 156 orang, wakil bupati 46 orang, wali kota 41 orang, dan wakil wali kota 20 orang. Ia menyebutkan tercatat juga 1.221 nama pegawai pemerintah yang terlibat dalam kasus korupsi. Dari jumlah tersebut, sebanyak 877-nya sudah menjadi terpidana. Sementara 185 orang lainnya sudah berstatus tersangka, sedangkan 112 orang lainnya sudah terdakwa, dan 44 nama tersisa masih dimintai keterangannya sebagai saksi. Sehingga tren korupsi yang ada saat ini harus diimbangi dengan alat pemberantasan korupsi yang juga cukup baik, di mana keberadaan KPK saat ini sudah sangat tepat dan diperlukan.4)

\footnotetext{
1) www.transparency.org, diakses tang gal 10 Februari 2017, jam 19.53 wib.

2) Ilyani Sudarjat, "Sumut dan Aceh, Juaranya Propinsi Terkorup Indonesia", www.regional.kompasiana.com, diakses 10 Februari 2017.

3) Anonim, “318 Kepala Daerah Terjerat Korupsi”, www.jpnn.com, diakses 10 Februari 2017.

4) Anonim, "318 Kepala Daerah Terjerat Korupsi”.
}

Faculty of Sharia and Law UIN Syarif Hidayatullah Jakarta -365 


\section{Sabungan Sibarani}

Undang-undang No. 12 Tahun 2008 tentang Perubahan Kedua Atas Undang-Undang Nomor 32 Tahun 2004 tentang Pemerintahan Daerah adalah undang-undang administratif. Terutama jika dikaitkan dengan pertanggungjawaban kepala daerah, undang-undang ini hanya mengatur pertanggungjawaban kepala daerah dari sudut hukum administrasi negara. Akan tetapi untuk hal-hal yang bersifat pidana yang dilakukan oleh kepala daerah, undang-undang ini tidak begitu banyak menyentuh hal tersebut.

Penulis menyoroti kasus korupsi yang terjadi di Propinsi Sumatera Utara, Propinsi Sumatera Utara termasuk propinsi dengan tingkat korupsi tertinggi atau terbesar di Indonesia mengingat banyak kasus atau permasalahan proyek fiktif, mark-up, bahkan sampai kepada permainan gratifikasi atau suap menyuap demi kelancaran tender proyek dan tumpang tindih proyek di instansi jajaran pemerintahan Provinsi Sumatera Utara dan daerah-daerah kabupaten/kota, serta permainan para koruptor dengan para oknum-oknum instansi hukum di Sumatera Utara ini sepertinya sudah sangat mengkawatirkan. Tolok ukurnya adalah kualitas pelayanan publik yang tercermin dalam komitmen anggaran dan keberadaan unit layanan pengaduan, anggaran pendidikan yang mengkhawatirkan, dan ini tentunya menghambat laju pembangunan. Pertama, sukses tidaknya pembangunan daerah sangat dipengaruhi oleh kualitas perencanaan dan penganggaran. Kedua, belum adanya sinkronisasi Rencana Pembangunan Jangka Menengah Daerah (RPJMD) dan perencanaan tahunan. Ketiga, siklus anggaran yang suka molor, dari 33 daerah hanya satu provinsi yang mengesahkan Perda APBD di bulan Oktober 2010 yaitu Sumatra Utara, sebagian besar di bulan Desember 2010 dan paling lambat adalah bulan April 2011.5)

\section{Upaya Walikota Medan dalam Mewujudkan Pemerintahan Yang Bersih di Pemerintah Daerah (Pemda) Kota Medan}

Pemerintah Daerah Kota Medan sebagai salah satu pemerintahan daerah kota yang berada di Provinsi Sumatera Utara. Pemerintah Kota Medan telah berupaya dalam meningkatkan pelayanan publik, dengan adanya program pengurusan Kartu Keluarga (KK) dan Kartu Tanda Penduduk (KTP) bagi masyarakat Kota Medan tidak dikenakan biaya administrasi. Ini

\footnotetext{
5) Anonim, "Dicari Warisan Pelayanan Publik yang Responsif", www.mic rosite.metrotvnews.com, diakses 10 Februari 2017.

366 - Jurnal Cita Hukum. Vol. 5 No. 2, December 2017. P-ISSN: 2356-1440. E-ISSN: 2502-230X
} 
menunjukkan upaya yang serius dalam peningkatan pelayanan publik dan kesejahteraan masyarakat, meskipun dalam peraktiknya di lapangan masih banyak warga masyarakat tetap membayar biaya administrasi tersebut.

Keberadaan Kota Medan sebagai Ibu Kota Provinsi Sumatera Utara, kondisi ini membuat pembangunan fisik Kota Medan mengalami perkembangan yang pesat, seiring dengan pertumbuhan penduduk dan pertumbuhan ekonomi (dunia usaha). Pembangunan pertokoan maupun perumahan penduduk berkembang dengan pesat.

Pada konteks pendayagunaan aparatur negara dalam kerangka reformasi birokrasi, semangat itu pula yang memberikan dorongan betapa pentingnya melakukan upaya upaya sistematis untuk mendayagunakan aparatur negara guna meningkatkan kualitas pelayanan publik dan mewujudkan good governance. Tidak dapat dipungkiri pula bahwa aparatur negara yang ideal merupakan suatu keniscayaan hakiki bagi keberlangsungan pembangunan nasional. Secara khusus, pelaksanaan upaya pendayagunaan aparatur negara dilakukan melalui upaya pembinaan, penyempurnaan, dan pengendalian manajemen pemerintahan dalam setiap aspek aparatur negara secara terencana, sistematis, bertahap, komprehensif, dan berkelanjutan untuk meningkatkan kinerja seluruh aparatur negara dalam rangka mewujudkan good governance. Hal ini, sejalan dengan kebijakan reformasi birokrasi yang secara substantif meliputi langkah dan upaya pada setiap aspek aparatur negara, melalui penataan kelembagaan dan ketatalaksanaan; penataan sistem kepegawaian; peningkatan kualitas pelayanan publik; serta peningkatan akuntabilitas dan sistem pengaw asan aparatur.

Sejalan dengan perkembangan terhadap berbagai aspek aparatur negara, terdapat satu isu yang mengemuka yang terjadi dala m perkembangan sektor publik di Pemda Kota Medan yaitu semakin menguatnya tuntutan akuntabilitas publik oleh lembaga lembaga publik. Akuntabilitas publik terkait 


\section{Sabungan Sibarani}

dengan good governance dipandang sebagai paradigma baru dan menjadi ciri yang perlu ada dalam sistem administrasi publik. ${ }^{6)}$

Penerapan Good Governance di sektor publik, khususnya di Pemda Kota Medan sangat berpengaruh terhadap keberhasilan terselenggaranya Good Governance pada sektor swasta/dunia usaha. Hal ini karena kebijakan publik diperlukan untuk mendorong terciptanya lingkungan yang kondusif bagi pemanfaatan peluang dan kegairahan kegiatan produktif masyarakat. Artinya bahwa peran pemerintah melalui kebijakan publik sangat penting, untuk memfasilitasi terjadinya mekanisme pasar dengan benar dan mencegah timbulnya monopoli komersial dan KKN (korupsi, kolusi dan nepotisme).

Membangun Good Governance di Pemda Kota Medan, bukan hanya masalah memperbaiki kondisi institusi pemerintah, kondisi pelaku dalam masyarakat juga hampir mendapat perhatian. Masyarakat sebagai institusi memiliki berbagai kelompok sosial dengan kondisi dan kepentingan berbeda. Oleh karena itu, Good Governance membutuhkan cara agar keragaman diperhitungkan, khususnya mengenai wilayah dan geografis Kota Medan.

Terselenggaranya Good Governance merupakan prasyarat bagi setiap pemerintahan untuk mewujudkan prasyarat bagi setiap pemerintahan untuk mewujudkan aspirasi masyarakat dan mencapai tujuan serta cita-cita bangsa bernegara. Dalam rangka itu diperlukan pengembangan dan penerapan sistem pertanggungjaw aban yang tepat, jelas dan legitimate, sehingga penyelenggaraan pemerintahan dan pembangunan dapat berlangsung secara berdayaguna, berhasil guna, bersih dan bertanggung jaw ab, serta bebas dari korupsi, kolusi, dan nepotisme.

Untuk itu diperlukan langkah-langkah untuk membangun penegakan hukum (Law enforcement) di Pemda Kota Medan yang akuntabel antara lain:

a. Perlunya penyempurnaan atau memperbaharui serta melengkapi perangkat hukum dan perundang-undangan yang ada;

b. Meningkatkan kualitas Sumber Daya Manusia (SDM) Penegak Hukum baik dari segi moralitas dan intelektualitasnya, karena tidak sedikit Penegak Hukum yang ada saat ini tidak paham betul idealisme hukum yang sedang ditegakkannya;

6) Sedarmay anti, Reformasi Administrasi Publik Reformasi Birokrasi, dan Kepemimpinan Masa Depan (Mewujudkan Pelayanan Prima dan Kepemerintahan Yang Baik), (Bandung: Refika Aditama, 2009), h. 270.

368 - Jurnal Cita Hukum. Vol. 5 No. 2, December 2017. P-ISSN: 2356-1440. E-ISSN: 2502-230X 
c. Dibentuknya suatu lembaga yang independen oleh Pemerintah dimana para anggotanya terdiri dari unsur-unsur masyarakat luas yang cerdas (non Hakim aktif, Jaksa aktif dan Polisi aktif) yang bertujuan mengawasi proses penegakan hukum (law enforcement) dimana lembaga ini berwenang merekomendasikan agar diberikannya sanksi bagi para penegak hukum yang melanggar proses penegakan hukum yang telah ditentukan. (vide: Pasal 9 ayat (1) dan (2) UU No. 4 tahun 2004 tentang Kekuasaan Kehakiman, Pasal 17 Jo. Pasal. 3 ayat [(2) dan (3)] Jo. Pasal. 18 ayat [(1) dan (4)] UU No. 39 tahun 1999 tentang Hak Asasi Manusia (HAM);

d. Perlu dilakukannya standarisasi dan pemberian tambahan kesejahteraan yang memadai khususnya bagi Penegak Hukum yang digaji yaitu: Hakim, Jaksa dan Polisi kecuali Advokat agar profesionalisme mereka sebagai bagian terbesar dari penegak hukum di Indonesia diharapkan lebih fokus dalam menegakkan hukum sesuai dari tujuan hukum itu sendiri;

e. Dilakukannya sosialisasi hukum dan perundang-undangan secara intensif kepada masyarakat luas sebagai konsekuensi a sas hukum yang mengatakan bahwa; "setiap masyarakat dianggap tahu hokum." Disini peran media cetak (Pers) dan media electronik (TV-Radio), serta kelompok-kelompok Lembaga Swadaya Masyarakat (LSM) sangat diperlukan, karena mereka banyak mengetahui dan concern dalam melakukan penyebaran informasi, serta melakukan "advokasi” kepada masyarakat, pemerintah dan pihak-pihak yang terkait agar terbangunnya prilaku dan kebudayaan hukum di negeri ini; dan

f. Perlu adanya good will yang melahirkan tekad (komitmen) bersama dari para penegakan hukum (law enforcement) yang konsisten. Komitmen ini diharapkan dapat lahir terutama dimulai dan diprakarsai oleh unsur penegak hukum yaitu "catur wangsa", terdiri dari: Hakim, Advokat, Jaksa dan Polisi, yang dari adanya komitmen ini diharapkan dapat pula diikuti oleh seluruh lapisan masyarakat, sehingga pada gilirannya akan lahir pula kebudayaan hukum di negeri ini;

Namun usul langkah-langkah di atas untuk membangun sistem penegakan hukum yang akuntabel tentu tidak dapat berjalan mulus tanpa ad a dukungan penuh dari Pemerintahan yang bersih (clean government), karena penegakan hukum (law enforcement) adalah bagian dari sistem hukum pemerintahan bahwa pemerintahan negara (lapuissance de executrice) harus menjamin kemandirian institusi penegak hukum yang dibaw ahinya dalam hal 


\section{Sabungan Sibarani}

ini institusi Kejaksaan dan Kepolisian karena sesungguhnya terjaminnya institusi penegakan hukum merupakan platform dari politik hukum pemerintah yang berupaya mengkondisikan tata-prilaku masyarakat Indonesia dalam kehidupan berbangsa dan bernegara agar tata-prilaku masyarakat tersebut mendukung tercapainya cita-cita bangsa Indonesia yang tedapat dalam alinea IV Pembukaan UUD 1945.

Pertanggungjawaban pidana hanya berkaitan dengan tanggung jaw ab pribadi pertanggungjawaban perdata berkaitan dengan baik tanggung jawab pribadi maupun tanggung jawab jabatan dan pertanggungjawaban administrasi berkaitan dengan tanggung jaw ab jabatan.

Pertanggungjawaban selain diatur dalam negara hukum juga diatur dalam negara demokrasi. Pertanggungjawaban hukum mengandung arti bahwa Pemerintah Daerah dalam menyelenggarakan pemerintahan yang merugikan kepentingan rakyat atau pihak lain harus mempertanggungjawabkan dan menerima tuntutan hukum atas tindakannya tersebut.7)

Pada intinya bahwa pertanggungjaw aban hukum Walikota Medan di Pemerintah Daerah Kota Medan seperti dijelaskan di atas selalu menekankan pada tanggungjawab pribadi dan tanggungjawab jabatan.

a. Tanggungjawab pribadi

Pertanggungjawaban pribadi berfokus pada pendekatan fungsional atau prilaku yang dapat mengakibatkan terjadinya tindakan penyalahgunaan wewenang dalam bentuk mal administrasi dan pertanggungjawaban jabatan yang berfokus pada pendekatan legalitas (keabsahan) mengenai penggunaan wewenang, prosedur dan substansi.

Tanggungjawab pribadi berkaitan dengan pendekatan fungsional atau prilaku, yang berkenaan tindakan sewenang-wenang atau penyalahgunaan wewenang (detournement de pouvoir) dalam bentuk mal administrasi. Mal administrasi adalah berarti pelayanan yang jelek. Dikaitkan dengan norma hukum administrasi, mal administrasi masuk kategori norma prilaku aparat dalam pelayanan publik.

Walikota Medan memiliki kewenangan dan bentuk tanggungjawab sebagai kepala pemerintahan, dimana hal itu harus dipertanggungjawabkan secara hukum bilamana mereka melakukan suatu tindak pidana atau

7) Ainur Rahman, Partisipasidan Demokras dalam Pembangunan,(Malang: Averroes Press, 2009), h. 71.

370 - Jurnal Cita Hukum. Vol. 5 No. 2, December 2017. P-ISSN: 2356-1440. E-ISSN: 2502-230X 
pelanggaran yang melanggar aturan atau ketentuan perundang-undangan yang berlaku.

Walikota Medan dalam hal ini mengemban amanat rakyat untuk mengatur, mengelola, menjaga dan membudidayakan nilai-nilail hukum terkait dengan berbagai implementasi atau kebijakan masalah pemerintahan dan itu tentunya harus dibarengi dengan banyak hal, artinya kebijakan itu harus mengacu pada nilai dan etika dari masyarakat Medan pada khususnya dan masyarakat Sumatera Utara pada umumnya. Jadi, intinya Walikota tidak kebal hukum dimana berbagai kebijakan harus bisa dipertanggungjawabkan secara hukum.

b. Tanggungjawab jabatan

Tanggung jawab jabatan berkenaan dengan legalitas (keabsahan) tindak pemerintahan yang berkaitan dengan penggunaan w ew enang, prosedur dan substansi. Penelaahan terhadap pertanggungjaw aban kepala daerah harus ditinjau dari dua segi. Pertama, dari segi kedudukan kepala daerah. Kedua, dari segi sistem pemerintahan daerah. Segi kedudukan kepala daerah seperti diuraikan di atas mencakup segi kepala wilayah administratif sebagai hasil dari proses dekonsentrasi dan segi kepala daerah otonom seagai hasil dari proses desentralisasi. Kedua segi ini, mungkin menyatu dalam satu tangan, mungkin terpisah satu sama lain dan mungkin pula dalam praktik organisasi, pemerintahan suatu negara salah satunya tidak diberlakukan. Secara teoritis penelaahan pertanggungjawaban kepala daerah harus diletakkan dalam masing-masing segi ini.

\section{Peranan Walikota Medan Untuk Mencegah Dan Menindak Pelaku Tindak Pidana Korupsi di Pemda Kota Medan}

Walikota Medan adalah sebagai kepala pemerintahan di wilayah kota administrasi Kota Medan. Dimana banyak peran dalam meningkatkan eksistensi dalam ruang lingkup pemerintahan daerah di Kota Medan. Tak terkecuali membangun pengawasan intern yang andal. Dalam membangun proses pengawasan intern yang andal, yang utama adalah membangun unit pengawasan intern yang capable, dimana hal ini mampu menjaga pengelolaan keuangan daerah agar terkelola secara efisien, efektif, taat aturan, bebas dari korupsi dan akuntabel. Dengan paradigma baru sebagai penjamin kualitas 


\section{Sabungan Sibarani}

(quality assurer) dan konsultan, inspektorat diharapkan akan membina jalannya pemerintahan dan pembangunan serta mencegah terjadinya penyimpangan.

Membangun unit pengawas intern yang kapabel sangat dipengaruhi oleh sosok pemimpin, yang dalam hal ini Walikota Medan tentang bagaimana persepsi pimpinan dan pihak pemangku kepentingan terhadap unit tersebut. Untuk membangun persepsi yang positif, yang utama adalah menunjukkan kinerja yang sebaik-baiknya. Proses pembangunan kapabilitas merupakan hasil proses berkelanjutan dan terus menerus yang dibangun pada setiap unsurnya.

Keberhasilan Walikota Medan tidak terlepas dari peran Walikota Medan untuk mencegah dan menindak pelaku tindak pidana korupsi di Pemda Kota Medan. Dalam menjalankan fungsi dan tugas, penyelenggara negara harus jujur, adil, terbuka dan terpercaya serta mampu membebaskan dari praktik Korupsi, Kolusi dan Nepotisme. Menghindarkan praktik-praktik Korupsi, Kolusi dan Nepotisme, seseorang yang terpercaya menjabat suatu jabatan dalam penyelenggaraan negara, harus bersumpah sesuai dengan agamanya, harus mengumumkan dan bersedia diperiksa kekayaannya sebelum dan setelah menjabat.

Upaya pemberantasan tindak pidana korupsi, dilakukan secara tugas dengan melaksanakan secara konsisten undang-undang tindak pidana korupsi. Pemberantasan Korupsi, Kolusi dan Nepotisme harus dilakukan secara tegas terhadap siapapun juga, baik pejabat negara, mantan pejabat negara, kelompok dan kroninya maupun pihak swasta/konglomerat dengan tetap memperhatikan prinsip praduga tak bersalah dan hak-hak asasi manusia. Penyelenggara negara mempunyai peran penting dalam mewujudkan cita-cita perjuangan bangsa. Hal ini secara tegas dinyatakan dalam penjelasan Undang-Undang Dasar 1945 yang menentukan bahwa yang sangat penting dalam pemerintahan dan dalam hal hidupnya negara ialah semangat para penyelenggara negara dan pemimpin pemerintahan.

Pegawai Negeri Sipil melaksanakan berbagai peran dalam negara demokrasi liberal, ada dua hal yang telah ditekankan secara tradisional: Pertama, Mereka memberi saran kepada yang menguji kendali tujuan politik 372 - Jurnal Cita Hukum. Vol. 5 No. 2, December 2017. P-ISSN: 2356-1440. E-ISSN: 2502-230X 
cabang pelaksana pada isi kebijakan. Kedua, Mereka dapat pula bertanggung jawab untuk melaksanakannya. Pelaksanaan kebijakan dilakukan di semua tingkatan pemerintahan dan termasuk pemberian pelayanan kepada publik/seperti pembayaran tunjangan kesejahteraan.

Birokrasi publik memiliki peran penting dalam pengelolaan kebijakan publik. Birokrat publik adalah para birokrat karir profesional yang memiliki pengalaman dalam pengelolaan kebijakan publik, sulit tertandingi oleh politikus dan pejabat politik. Birokrat publik adalah profesional yang dengan sukarela mengabdikan hidupnya dalam birokrasi, mereka tidak dipilih, tetapi melamar untuk menjalankan karirnya dalam birokrasi publik. Pemerintahan hanya akan dapat dijalankan oleh birokrat profesional yang memang berkarir dalam bidang itu. Birokrasi publik merupakan pilar keempat dalam negara demokrasi setelah legislatif, yudikatif, dan eksekutif.

Di sini fungsi dari seorang pimpinan sangat diperlukan dalam menghadapi pegawai yang memiliki permasalahan tersebut, hal ini sejalan dengan pendapat Rivai menjelaskan, secara operasional dapat dibedakan dalam lima fungsi pokok kepemimpinan yaitu: ${ }^{8)}$

\section{a. Fungsi Instruktif}

Fungsi ini bersifat komunikasi satu arah. Pemimpin sebagai komunikator merupakan pihak yang menutup apa, bagaimana dan di mana perintah itu dikerjakan agar keputusan dapat dilaksanakan secara efektif memerlukan kemampuan untuk menggerakkan dan memotivasi orang lain agar mau melaksanakan perintah.

\section{b. Fungsi Konsultatif}

Fungsi ini bersifat komunikasi dua arah. Pada tahap pertama dalam usaha menetapkan keputusan, pemimpin kerap kali memerlukan bahan pertimbangan, yang mengharuskannya bekonsultasi dengan orang-orang yang dipimpinnya yang nilai mempunyai berbagai bahan informasi dari pimpinan pada orang-ornag yang dipimpin dapat dilakukan setelah keputusan ditetapkan dan sedang dalam pelaksanaan. Konsultasi itu dimaksudkan untuk memperoleh masukan berupa umpan balik (feed back) untuk memperbaiki dan

8) Rivai, Kepemimpinan Era Modern, (Jakarta: Djambatan, 2009), h. 74.

Faculty of Sharia and Law UIN Syarif Hidayatullah Jakarta - 373 


\section{Sabungan Sibarani}

menyempurnakan keputusan-keputusan yang telah ditetapkan dan dilaksanakan. Dengan menjelaskan fungsi konsultatif dapat diharapkan keputusan-keputusan pimpinan, akan mendapatkan dukungan dan lebih mudah menginstruksikannya, sehingga kepemimpinan berlangsung efektif.

c. Fungsi Partisipasi

Dalam menjalankan fungsi ini pemimpin berusaha mengaktifkan orang-orang yang dipimpinnya, baik dalam keikutsertaan mengambil keputusan maupun dalam melaksanakannya. Partisipasi tidak berarti bebas berbuat semuanya, tetapi dilakukan secara terkendali dan terarah berupa kerjasama dengan tidak mencampuri atau mengambil tugas pokok orang lain. Keikutsertaan pemimpin harus tetap dalam fungsi sebagai pemimpin dan bukan pelaksana.

d. Fungsi Delegasi

Fungsi ini dilaksanakan dengan memberikan pelimpahan wewenang membuat/menetapkan keputusan, baik melalui persetujuan maupun tanpa persetujuan dari pimpinan. Fungsi delegasi pada dasarnya berarti kepercayaan orang-orang penerima delegasi itu harus diyakini merupakan pembantu pemimpin yang memiliki prinsip, persepsi dan aspirasi.

e. Fungsi Pengendalian

Fungsi pengendalian bermaksud bahwa kepemimpinan yang sukses/efektif mampu mengatur aktivitas anggotanya secara terarah dan dalam koordinasi yang efektif, sehingga memungkinkan tercapainya tujuan bersama secara maksimal. Fungsi pengendalian dapat diwujudkan melalui kegiatan bimbingan, pengarahan, koordinasi, dan pengawasan.

Faktor penghambat dalam upaya peningkatan disiplin di Pemda Kota Medan ini antara lain: karena kurangnya sarana prasarana yang memadai khususnya penyediaan listrik, PAM, juga yang lebih penting adalah individu itu sendiri dalam melaksanakan semua aturan-aturan yang berlaku terkadang tidak mengindahkan peraturan tersebut. Untuk itu hendaknya kepada para pegaw ai untuk dapat meningkatkan lagi disiplin tersebut dengan cara mencari solusi yang dapat mengatasi penghambat dalam peningkatan disiplin kerja pegawai. Sedangkan faktor pendukung adalah terdapat beberapa pegawai yang memilik motivasi yang tinggi dan juga ingin berprestasi.

Hasil wawancara peneliti dengan Bapak Sori Tua Harahap di Biro Hukum Pemda Kota Medan adalah “apa saja faktor penghambat dan faktor pendukung dalam upaya peningkatan disiplin kerja pegawai di lingkungan 374 - Jurnal Cita Hukum. Vol. 5 No. 2, December 2017. P-ISSN: 2356-1440. E-ISSN: 2502-230X 
Pemda Kota Medan?" hasil jawaban beliau tentang hambatan atau kendala yang ditemui antara lain: ${ }^{9)}$

a. Tinggi tingkat kemangkiran (absensi) pegawai.

b. Tingginya tingkat keterlambatan saat masuk kantor atau pulang lebih awal dari yang sudah ditentukan.

c. Para pegawai tidak mempunyai semangat dan gairah kerja.

d. Berkembangnya rasa tidak puas, saling curiga dan saling melemparkan tanggung jawab.

e. Tidak tercapainya penyelesaian pekerjaan tepat waktu, kar ena pegawai lebih banyak menghabiskan waktu untuk kegiatan yang tidak ada hubungannya dengan pekerjaan.

f. Tidak terlaksananya supervisi dan pengaw asan dari atasan.

g. Sering terjadinya konflik antar pegawai.

Perlu diketahui bahwa, tindak pidana korupsi dalam ruang lingkup Pemda Kota Medan tidak terlepas atas keberadaan pejabat atau PNS dalam ruang lingkup Pemda Kota Medan. Dalam hal ini perlu peran Walikota Medan guna menindak pelaku tindak pidana korupsi, dan ini tentunya dimulai dengan menjalankan fungsi kepemimpinannya agar para pegawai tidak lagi melanggar aturan-aturan atau ketentuan-ketentuan yang telah dibuat dan disepakati. Selan itu juga hendaknya para pegawai dapat meningkatkan lagi disiplinnya dengan tujuan memperoleh prestasi yang lebih tinggi lagi di kantor usaha dalam mengatasi ketidakdisiplinan pegawai tersebut dapat dilakukan oleh pimpinan dengan menjalankan fungsi kepemimpinannya. Disiplin dan produktivitas kerja pegawai merupakan sebagian dari indikator perilaku pegawai yang positif sebagaimana yang dikehendaki dalam kepemimpinan suatu organisasi. Sejalan dengan hal tersebut, berfungsi tidaknya seorang pemimpin sangat menentukan dalam meningkatkan keberhasilan suatu organisasi pada masa mendatang.

Pejabat atau Pegaw ai Negeri Sipil dilingkup Pemda Kota Medan sangat penting dan menentukan karena sebagai pelaksana kebijakan publik dalam mencapai tujuan yang diinginkan. Untuk itu dalam upaya mewujudkan tujuan tersebut harus ada kerjasama yang baik antar lini departemen dan juga masyarakat. Meskipun program Pemerintah terencana dengan baik tetapi

9) Wawancara dengan Sori Tua Harahap selaku pegawai di Biro Hukum Pemda Kota Medan, tang gal 12 Januari 2017, jam. 13.00 WIB.

Faculty of Sharia and Law UIN Syarif Hidayatullah Jakarta - 375 


\section{Sabungan Sibarani}

apabila masyarakat tidak mendukung maka tidak akan terjadi pelaksanaan program pemerintah dengan baik. ${ }^{10)}$

Berpijak pada uraian di atas, pejabat atau Pegaw ai Negeri Sipil dalam lingkup Pemda Kota Medan tidak hanya dituntut kehadiran di kantor saja, melainkan juga dituntut untuk mempunyai dedikasi yang tinggi, semangat dan kedisiplinan yang tinggi dalam melaksanakan tugas. Pejabat atau Pegawai Negeri Sipil yang berkualitas menjadi salah satu tolak ukur bagi terselenggaranya pelaksanaan tugas yang baik sehingga efektifitas pemerintahan yang baik (good governance) dapat terwujud. ${ }^{11)}$

Beberapa poin penting yang terkait dengan implementasi prinsipprinsip Good Governance merupakan pegangan bagi birokrasi publik dalam melakukan transformasi manajemen pemerintahan. Tuntutan ke arah Good Governance juga lahir akibat kualitas pelayanan publik yang rendah. Untuk itu diharapkan adanya penyelenggaraan kepemerintahan yang baik tingkat kompetensi aparatur seperti misalnya dengan memiliki pegangan seperti antara lain:

a. Insentif dan responsif terhadap peluang dan tantangan baru yang timbul.

b. Tidak terpaku pada kegiatan-kegiatan rutin yang terkait dengan fungsi instrumen birokrasi, akan tetapi harus mampu melakukan terobosan melalui pemikiran yang kreatif dan inovatif.

c. Mempunyai wawasan yang luas dan jauh kedepan.

d. Memiliki kemampuan untuk mengantisipasi, mempertimbangkan dan meminimalkan resiko.

e. Tanggap terhadap peluang dan potensi yang dapat dikembangkan.

Sebagai contoh pejabat atau PNS yang diduga melakukan tindak pidana korupsi di Pemda Kota Medan, dimana dalam hal ini pejabat atau PNS tersebut melanggar Undang-Undang No. 20 Tahun 2001 tentang Perubahan atas Undang-Undang No. 31 Tahun 1999 tentang Pemberantasan Tindak Pidana Korupsi, dalam hal ini dapat dilihat pada tabel 1 berikut ini.

10) Inu Kencana, Kepemimpinan Pemerintahan, (Jakarta: Pustaka Ilmu, 2007), h. 33.

11) Wursanto, Kepemimpinan dalam Pemerintahan, (Jakarta: Djambatan, 2009), h. 2. 
Tabel 1

Jumlah Pejabat (pegawai) yang diduga melakukan tindak pidana korupsi

\begin{tabular}{|l|c|}
\hline \multicolumn{1}{|c|}{ Dinas } & $\begin{array}{c}\text { Yang diduga melakukan tindak } \\
\text { pidana korupsi }\end{array}$ \\
\hline Dinas Perhubungan & 2 \\
\hline Dinas Kependudukan & 2 \\
\hline Dinas Pendidikan & 4 \\
\hline Dinas Tata Ruang dan Kota & 3 \\
\hline Dinas Kesehatan & 2 \\
\hline
\end{tabular}

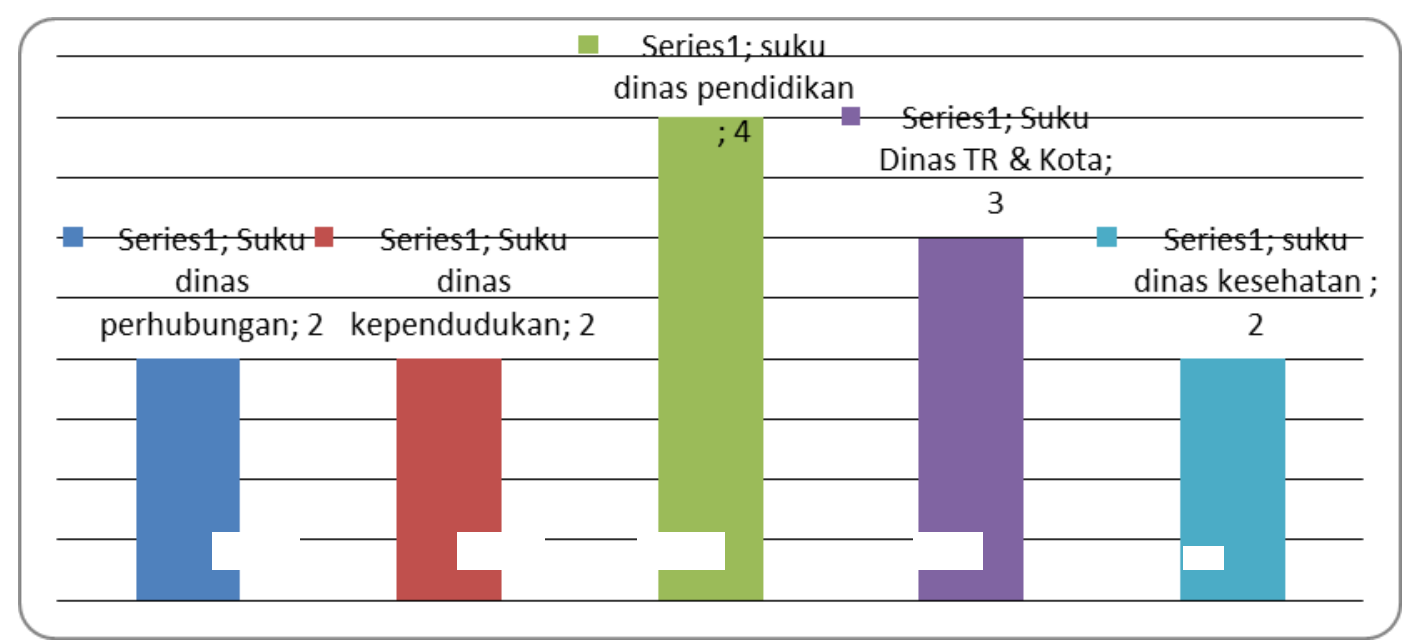

Sumber: Kantor Pemda Kota Medan

\section{Gambar 1}

\section{Jumlah Pejabat (pegawai) yang Diduga Melakukan Tindak Pidana Korupsi di Kantor Pemda Kota Medan}

Berdasarkan wawancara peneliti dengan Anrini Sitompul, selaku Asisten Sekda beliau menyatakan bahwa pejabat PNS yang diduga terlibat tindak pidana korupsi di Kantor Walikota Medan ada 13 dinas dan mereka telah diberikan sanksi sebelumnya, yaitu peringatan pertama, kedua dan ketiga. Sedangkan tanggungjawab pejabat/PNS yang diduga terlibat tindak pidana korupsi tersebut diproses secara hukum sehingga menimbulkan efek jera dan tidak mengulangi lagi perbuatannya. Berkenaan dengan pemerintah 


\section{Sabungan Sibarani}

bersih beliau mengatakan bahwa penegakan disiplin pejabat atau PNS mengacu pada PP No. 53 Tahun 2010 tentang Disiplin PNS. ${ }^{12)}$

Sekretaris Pemda Medan, Syaiful Bahri menyebutkan "penggunaan anggaran di daerah sudah melalui pengawasan ketat, baik secara internal melalui inspektorat, maupun eksternal dari Badan Pemeriksa Keuangan (BPK), juga oleh masyarakat. Dengan demikian, penyimpangan anggaran sulit dilakukan. Ini tentunya patut diapresiasi dan diaw asi bersama, baik dari unsur LSM, instansi terkait dan masyarakat. Sedangkan 80-90 persen selebihnya masih berkutat pada pegawai teknis, seperti staf, kepala seksi, kepala bagian, atau pejabat setingkatnya. "Pejabat eselon tinggi seperti kepala dinas yang kena (korupsi) baru 10-20 persennya, selebihnya pegawai rendahan. ${ }^{13)}$

Pemecatan bagi pejabat atau PNS dalam lingkup Pemda Kota Medan yang terlibat tindak pidana jabatan tadijuga dikuatkan dalam PP 32/1979. Pada Pasal 9 PP tersebut diatur bahwa PNS diberhentikan dengan tidak hormat ketika melakukan suatu tindak pidana jabatan atau tindak pidana kejahatan yang berhubungan dengan jabatan. Sayan gnya pada prakteknya sanksi kepada PNS yang terlibat korupsi, terutama yang tuntutan hukumannya kurang dari empat tahun, tidak berujung pemecatan. Sebab, jenis pidana yang didakwakan kepada PNS nakal ini bukan tindak pidana jabatan, tetapi tindak pidana kejahatan biasa. Sebagaimana sudah diatur PNS yang divonis dengan dengan kurang dari empat tahun, bisa terhindar dari pemecatan. ${ }^{14)}$

Penegakkan hukum di kalangan pejabat/PNS Pemda Kota Medan diperlukan sistem hukum yang baik dengan cara merubah paradigma dala m hukum kepegawaian yang bukan hanya berorientasi untuk memenuhi kebutuhan masyarakat. Hal ini akan berkaitan dengan prinsip meritokrasi dimana inti dari prinsip ini adalah jenis penguatannya (reinforcement) melalui reward dan punishment. Prinsip tersebut akan mengarah pada penegakan hukuman disiplin yang natural dan berimbang, yang didalamnya akan terkandung aspek kompetensi dan aspek peningkatan kualitas SDM aparatur yang berorientasi untuk memenuhi kebutuhan masyarakatnya. Jadi menurut pendapat peneliti, peranan Walikota Medan untuk mencegah dan menindak pelaku tindak pidana korupsi di Pemda Kota Medan adalah:

\footnotetext{
12) Wawancara deng an Anrini Sitompul, Asisten Sekda Pemerintah Daerah Kota Medan, tanggal 13 Januari 2017, jam. 11.00 WIB.

13) Wawancara dengan Bapak Syaiful Bahri selaku Sekda Medan pada tanggal 12 Januari 2017, pukul 12.00 WIB.

14) Miftah Thoha, Manajemen Kepegawaian Sipil Di Indonesia, (Jakarta: Kencana Perdana Media Group, 2010), h. 69.

378 - Jurnal Cita Hukum. Vol. 5 No. 2, December 2017. P-ISSN: 2356-1440. E-ISSN: 2502-230X
} 
a. Membangun proses pengawasan intern yang andal, yang utama adalah membangun unit pengaw asan intern yang kapabel, dimana hal ini ma mpu menjaga pengelolaan keuangan daerah agar terkelola secara efisien, efektif, taat aturan, bebas dari korupsi dan akuntabel.

b. Mengedepankan prinsip transparansi dalam menjalankan fungsi dan tugas jabatannya guna mencegah terjadinya praktek korupsi di wilayahnya. Mencegah korupsi dapat dilakukan selain dengan prinsip transparansi, perlu juga membangun pagar-pagar pengaman agar semua bisa terjaga dari praktik korupsi. Juga perlu ada sistem teknologi informasi, agar masyarakat bisa mengawasi APBD yang dipaparkan melalui website, begitu juga dengan pajak harus online.

c. Membuat program peringatan dini pencegahan korupsi. Seluruh pejabat eselon di lingkup Pemda Kota Medan membuat Laporan Harta Kekayaan Penyelenggara Negara dan diserahkan ke KPK dan ini dimulai Walikota Medan.

d. Tak terkalah penting diperlukan sembilan langkah untuk pemberantasan korupsi, diantaranya dengan penataan struktur birokrasi, penataan jumlah distribusi PNS, sistem seleksi dan promosi secara terbuka, profesionalisasi PNS, pengembangan sistem elektronika pemerintah (e-government), peningkatan pelayanan publik, peningkatan transparansi dan akuntabilitas aparatur, peningkatan kesejahteraan pegaw ai negeri, efisiensi penggunaan fasilitas, sarana dan prasaranan kerja PNS.

e. Walikota Medan sebagai kepala daerah harus mampu menunjukkan perilaku kepemimpinan yang bersih dari KKN dan mampu memberikan informasi, konsultasi dan delegasi, perencanaan dan pengorganisasian, pemecahan masalah, merumus peran dan tujuan, monitoring, motivasi, pengakuan dan penghargaan, dukungan, dan membuat jaringan kerja yang sinergi dengan kondisi dan budaya di Kota Medan, sehingga prakek korupsi dari level bawah hingga level atas di lingkup Pemda Kota Medan bisa secara dini diatasi.

f. Walikota Medan harus memiliki akuntabilitas publik yang merupakan sinergi dari akuntabilitas manajerial, akuntabilitas proses dan akuntabilitas program terkait dengan program pencegahan tindak pidana kor upsi dan pemberdayaan pegawai/pejabat di lingkungan Pemda Medan untuk tidak melakukan tindak pidana korupsi mengingat sanksi yang diberikan cukup berat yakni peringatan, pemecatan dan tak terberat dihukum sesuai dengan peraturan hukum yang berlaku. 


\section{Sabungan Sibarani}

\section{Kesimpulan}

Upaya Walikota Medan dalam mew ujudkan pemerintah yang bersih di Pemerintah Daerah Kota Medan, peneliti menemukan beberapa kesimpulan, Pertama, menjalankan peraturan daerah yang dibuat dan melakukan terobosan-terobosan yang berhubungan dengan proses penegakan hukum, khususnya bagi pejabat/PNS yang diduga melakukan tindak pidana korupsi di lingkup Pemda Kota Medan dan menindak tegas bagi pejabat di lingkungan Pemda Kota Medan yang diduga melakukan tindak pidana korupsi dan menyerahkannya ke proses hukum yang berlaku. Kedua, selalu berpedoman pada hal-hal berikut, diantaranya (a) Fakta Integritas, (b) e-purchasing, (c) egovernment, (d) penghargaan (reward) dan hukuman (punishment), (e) Wajar Tanpa Pengecualian (WTP) dan Unit Layanan Pengadaan (ULP).

Sedangkan peranan Walikota Medan untuk meningkatkan pencegahan dan penindakan pelaku tindak pidana korupsi di Pemda Kota Medan, peneliti menemukan berbagai peran Walikota, diantaranya adalah Pertama, mengedepankan prinsip transparansi dalam menjalankan fungsi dan tugas jabatannya guna mencegah terjadinya praktek korupsi di wilayahnya. Kedua, membuat program peringatan dini pencegahan korupsi. Seluruh pejabat eselon di lingkup Pemda Kota Medan membuat Laporan Harta Kekayaan Penyelenggara Negara dan diserahkan ke KPK dan ini dimulai Walikota Medan. Ketiga, menggunakan 9 (sembilan) langkah pemberantasan korupsi di Pemda Kota Medan, diantaranya : (a) dengan penataan struktur birokrasi, (b) penataan jumlah distribusi PNS, (c) sistem seleksi dan promosi secara terbuka, (d) profesionalisasi PNS, (e) pengembangan sistem elektronika pemerintah (egoverment), (f) peningkatan pelayanan publik, (g) peningkatan transparansi dan akuntabilitas aparatur, (h) peningkatan kesejahteraan pegawai negeri, (i) efisiensi penggunaan fasilitas, sarana dan prasaranan kerja PNS. 


\section{Daftar Pustaka}

\section{Buku}

Kencana, Inu, Kepemimpinan Pemerintahan, Jakarta: Pustaka Ilmu, 2007.

Rahman, Ainur. Partisipasi dan Demokras dalam Pembangunan, Malang: Averroes Press, 2009.

Rivai, Kepemimpinan Era Modern, Jakarta: Djambatan, 2009.

Sedarmayanti. Reformasi Administrasi Publik Reformasi Birokrasi, dan Kepemimpinan Masa Depan (Mewujudkan Pelayanan Prima dan Kepemerintahan Yang Baik), Bandung: Refika Aditama, 2009.

Thoha, Miftah, Manajemen Kepegawaian Sipil Di Indonesia, Jakarta: Kencana Perdana Media Group, 2010.

Wursanto, Kepemimpinan dalam Pemerintahan, Jakarta: Djambatan, 2009.

\section{Internet}

Anonim. "318 Kepala Daerah Terjerat Korupsi”, http://w w w.jpnn.com/read/2014/02/15/216728/318-Kepala-DaerahTerjerat-Korups, diunduh 10 Februari 2017.

Anonim. "Dicari Warisan Pelayanan Publik yang Responsif". http://microsite.metrotvnews.com/front/kolom/2013/09/01/338/DicariWarisan-Pelayanan-Publik-yang-Responsif/kolom, diunduh 10 Februari 2017.

Sudarjat, Ilyani. "Sumut dan Aceh, Juaranya Propinsi Terkorup Indonesia". http://regional.kompasiana.com/2013/07/23/sumut-dan-aceh-juaranyaprovinsi-terkorup-indonesia-575965.html, diundh 10 Februari 2017.

www.transparency.org, diunduh tanggal 10 Februari 2017, jam 19.53 wib.

\section{Wawancara}

Wawancara dengan Anrini Sitompul, Asisten Sekda Pemerintah Daerah Kota Medan, tanggal 13 Januari 2017, jam. 11.00 WIB. 


\section{Sabungan Sibarani}

Wawancara dengan Bapak Syaiful Bahri selaku Sekda Medan pada tanggal 12 Januari 2017, pukul 12.00 WIB.

Wawancara dengan Sori Tua Harahap selaku pegawai di Biro Hkum Pemda Kota Medan, tanggal 12 Januari 2017, jam. 13.00 WIB. 